\title{
Plasma and urine levels of calcium, phosphorus and magnesium in growing cats
}

\author{
Níveis plasmáticos e urinários de cálcio, fósforo e magnésio em gatos em crescimento \\ Félix Diaz González², Felipe Duarte², Alexandre de Brum², Cácia Capp², \\ Verônica La Rosa ${ }^{3}$, Cristiano Weissheimer ${ }^{2}$, João Antônio Pigatto ${ }^{4}$ \& Luciana Lacerda ${ }^{2}$
}

\begin{abstract}
Feline lower urinary tract disease affects $1 \%$ worldwide population of cats. This disease may be predisposed by uroliths formation. Incidence of urolithiasis is related to feeding, mainly to macromineral composition. Balance of calcium, phosphorus and magnesium, and urinary $\mathrm{pH}$ are the main factors related to urolithiasis. The present work aims to study the metabolism of those minerals in growing cats, evaluating their plasma and urinary levels. There were used 10 cats of both sexes, 3 month-old, feeding a commercial ration until 1 year-old. Every 30 days, there were collected samples of blood and urine, to determine mineral concentrations and $\mathrm{pH}$ and creatinine levels of urine. At same intervals, there were determined the mineral content of the ration. Weekly feed consumption and body weight were registered. Mean levels of calcium, phosphorus and magnesium in plasma were, respectively, $8.77 \pm 1.9 \mathrm{mg} / \mathrm{dL}, 7.55 \pm 1.8 \mathrm{mg} / \mathrm{dL}$ and $2.66 \pm 0.67 \mathrm{mg} / \mathrm{dL}$. Variation along the year is showed. Less variation was that of calcium, followed by magnesium and higher variation was that of phosphorus. Mean values of the minerals in urine, in relation to creatinine, were $1.29 \pm 1.0 \times 10^{-2}$ for $\mathrm{Ca}, 1.46 \pm 1.1$ for $\mathrm{P}$ and $7.87 \pm 7.7 \times 10^{-2}$ for $\mathrm{Mg}$. $\mathrm{Ca} / \mathrm{P}$ relation in the feed was $2.87 \pm 1.2$, considered high. $\mathrm{Mg}$ content in feed was higher than nutritional requirements. Mean value of urinary $\mathrm{pH}$ was $6.25 \pm 0.54$, considered adequate to prevent urolithiasis by struvite but not to prevent crystal formation of calcium oxalate.
\end{abstract}

Key words: calcium, phosphorus, magnesium, excretion, urine, cats.

\section{RESUMO}

A doença do trato urinário inferior dos felinos atinge $1 \%$ da população mundial de gatos, tendo como fator predisponente a formação de urólitos. A incidência de urolitíase está relacionada com a alimentação, principalmente com o conteúdo de macrominerais. $\mathrm{O}$ balanço de cálcio, fósforo e magnésio e o $\mathrm{pH}$ da urina são os principais fatores relacionados com urolitíase. $\mathrm{O}$ presente trabalho teve por objetivo estudar o metabolismo desses minerais em gatos em crescimento, mediante a avaliação dos seus teores sanguiíneos e urinários. Foram utilizados 10 gatos com 3 meses de idade, alimentados com ração comercial até completar 1 ano de idade. A cada 30 dias foram coletadas amostras de sangue e urina, para determinar concentrações dos minerais e valores de pH e creatinina urinários. No mesmo intervalo, foi determinado o conteúdo desses minerais na ração. Semanalmente foram registrados consumo de ração e peso dos animais. Os níveis médios de cálcio, fósforo e magnésio no plasma foram, respectivamente, $8,77 \pm 1,9 \mathrm{mg} / \mathrm{dL}, 7,55 \pm 1,8 \mathrm{mg} / \mathrm{dL}$ e 2,66 $\pm 0,67 \mathrm{mg} / \mathrm{dL}$. São mostradas variações mensais desses valores. A menor variação foi de cálcio, seguido de magnésio e a maior variação foi do fósforo. Os valores médios dos minerais na urina medidos pela relação com creatinina foram de $1,29 \pm 1,0 \times 10^{-2}$ para Ca, de $1,46 \pm 1,1$ para $\mathrm{Pe}$ de $7,87 \pm 7,7 \times 10^{-2}$ para $\mathrm{Mg}$. A relação Ca/P da ração foi de $2,87 \pm 1,2$, considerada alta. O valor de $\mathrm{Mg}$ na ração foi maior que as exigências. O valor médio do $\mathrm{pH}$ urinário foi de $6,25 \pm$ 0,54, foi considerado adequado na prevenção de urolitíase por estruvita mas não na formação de cristais de oxalato de cálcio.

Descritores: cálcio, fósforo, magnésio, excreção, urina, gatos.

${ }^{1}$ Setor de Análises Clínicas Veterinárias, Departamento de Patologia de Clínica Veterinária (DPCV), Faculdade de Veterinária (FAVET), Universidade Federal do Rio Grande do Sul (UFRGS). ${ }^{2}$ Fellowship students. ${ }^{3}$ Laboratory Technician. ${ }^{4}$ Departamento de Medicina Animal, FAVET-UFRGS. CORRESPONDENCE: F. D. González [e-mail: felixgon@orion.ufrgs.br ; Fax: +55 513316 7305]. Caixa Postal 15094; 91501-970 Porto Alegre, RS - Brazil. 


\section{INTRODUCTION}

Feline lower urinary tract disease (FLUTD) affects $1 \%$ of worldwide population of cats [15]. Generally, this disease constitutes a challenge for small animal clinicians due to its complex etiology and its high rate of relapses, which can reach $40 \%$ of the cases [12].

An important predisposed factor of FLUTD is the presence of uroliths, which can obstruct urinary tract. Urolithiasis is common in cats, mainly in males [4]. Nearly $22 \%$ of feline lower urinary tract diseases are concurrent with urolithiasis [9]. The more frequent uroliths found in cats are those of struvite, composed by magnesium-ammonium phosphates $\left(\mathrm{MgNH}_{4} \mathrm{PO}_{4}\right.$. $6 \mathrm{H}_{2} \mathrm{O}$ ), which may comprise $65 \%$ of feline uroliths [2]. Calcium oxalate uroliths may include nearly $19 \%$ of the cases [11].

Urolithiasis incidence is related to feeding, mainly as a function of magnesium contents of diet, as magnesium homeosthasis is basically maintained through its urine excretion [7]. Feline urolithiasis is associated with diets high in magnesium and alkaline urine [14]. Buffington [3] reported an experimental urolithiasis in cats feeding diets with 0.15 to $1.0 \%$ of magnesium (dry matter basis). Magnesium excretion and urinary concentrations are highly related to minerals consumption. Higher consumption of calcium appears to diminish intestinal absorption of magnesium and phosphorus, thereby, reducing urinary concentration of those late minerals [13].

Urinary calculi epidemiology in cats, however, seems to be changing. Struvite calculi are diminishing and calcium oxalate calculi are increasing [4]. This is because cat rations content less magnesium and are using urine acidificants, like ammonium and methionine chloride.

Not all cats develop urinary-tract blockage when consuming high levels of magnesium, indicating that many other factors could be involved in the problem [16]. Knowledge of nutritional factors associated to uroliths formation pathology is more necessary, particularly because of the high number of commercial rations and the lack of control methods of urolithiasis incidence.

The present work has the aim to contribute to the study of macrominerals metabolism (calcium, phosphorus and magnesium) in growing cats feeding a commercial ration, by determining plasma and urine levels of the minerals along the first year age.

\section{MATERIALS AND METHODS}

Ten cats of undefined breed, 3-month-old, of both sexes were used in the experiment. The animals were clinically evaluated before the study in order to confirm their healthy condition and were maintained in a collective box. The cats were vaccinated against rabies, feline panleukopenia and rhinotracheitis, as well as everminated before the study.

The cats were fed with a commercial ration in specified quantities according to their body weight, as recommended by the manufacturer. Clean drinking water was maintained always. Guaranteed analysis of the ration is showed in Table 1. Nutritional requirements preconized by NRC [10] for growing cats are $0.8 \%$ for $\mathrm{Ca}, 0.6 \%$ for $\mathrm{P}$ and $0.04 \%$ for $\mathrm{Mg}$.

Every 30 days, beginning 15 days after boxing to let adaptation of the animals, were collected samples of blood from jugular vein with heparin-vacutainer tubes and samples of urine by cystocentesis. Sampling was done in fasting conditions from 3 to 12 month-old. All the animals were weighed weekly in order to calculate the feed quantity. Blood samples were centrifuged immediately after collecting to obtain plasma, which was frozen until determination of mineral concentration.

At the same intervals (30 days), ration samples were aleatory collected to determine calcium, phosphorus and magnesium contents.

Calcium, phosphorus and magnesium concentrations were determined in blood and urine samples. There was also determined urine concentration of creatinine and urine $\mathrm{pH}$. Mineral concentration in blood and urine was determined by photocolorimetric methods. Magnesium by Mann and Yoe method, ${ }^{1}$ calcium by cresolftalein method, ${ }^{2}$ phosphorus by ammonium molibdate method ${ }^{3}$ and creatinine by picrate method. ${ }^{1}$ The $\mathrm{pH}$ values were determined in a digital

Table 1. Guaranteed analysis (\%) by manufacturer of the rations used in the experiment.

\begin{tabular}{ccc}
\hline Component & Kitten* $^{*}$ & Adult* \\
\hline Crude protein (min.) & 34 & 32 \\
Ether extract (min.) & 22 & 21 \\
Fiber (max.) & 3 & 3 \\
Calcium (max.) & 1.5 & 1.2 \\
Phosphorus (min.) & 0.8 & 0.7 \\
Mineral matter (max.) & 8 & 8 \\
\hline *Kitten ration was offered until 6 month-old. Adult ration from \\
6 to 12 month-old.
\end{tabular}


$\mathrm{pH}$ meter. ${ }^{4}$ Mineral contents in ration were performed by atomic absorption spectrophotometry.

Data were statistically analyzed to obtain descriptive values (mean, standard deviation).

\section{RESULTS}

Overall mean value of plasma calcium was $8.77 \pm 1.9 \mathrm{mg} / \mathrm{dL}$. Mean urinary calcium, measured by calcium/creatinine ratio was $0.013 \pm 0.01$. Values expressed in $\mathrm{mg} / \mathrm{kg} /$ day was $1.09 \pm 0.7$. Variations of plasma calcium in the growing cats along the first year of age are shown in Figure 1. Variations of calcium excretion by urine expressed as calcium/creatinine ratio are shown in figure 2.

Plasma phosphorus mean was $7.55 \pm 1.8 \mathrm{mg} /$ $\mathrm{dl}$. The mean phosphorus/creatinine ratio in urine was $1.46 \pm 1$.1. Urine mean phosphorus concentration expressed in $\mathrm{mg} / \mathrm{kg} /$ day was $98.4 \pm 86.9$. Variations of plasma levels and urinary excretion of phosphorus are shown in figures 3 and 4, respectively. Those variations were much larger in the case of phosphorus than in calcium.

Plasma magnesium mean value was $2.66 \pm$ $0.67 \mathrm{mg} / \mathrm{dL}$. Urine magnesium had a mean of $5.69 \pm$ $3.9 \mathrm{mg} / \mathrm{kg} / \mathrm{day}$. In terms of magnesium $/$ creatinine ratio the value was $0.078 \pm 0.07$. Figures 5 and 6 show the variations of this mineral in plasma and urine along the first year of age of cats studies. Urinary $\mathrm{pH}$ mean value was $6.25 \pm 0.54$ with a tendency of being less acidic with aging (Figure 7).

\section{DISCUSSION}

Mean value of plasma calcium was within the reference values $(6.2-10.2 \mathrm{mg} / \mathrm{dL})$ cited by Kaneko et al. [8]. There were limited variations along the year (Figure 1), following the rigorous endocrine control of calcemia.

Mean urinary calcium was higher than reference interval $(0.20-0.45 \mathrm{mg} / \mathrm{kg} / \mathrm{day})$ cited by Kaneko et al. [8]. Variation of calcium concentration in urine was higher than in plasma, reflecting the importance of renal excretion mechanism in the maintenance of calcemia (Figure 2).

Mean value of calcium in the ration was 2.27 $\pm 0.39 \%$ (dry matter basis), higher than the guaranteed content specified by the manufacturer (Table 1) and than $0.8 \%$ requirement preconized by the NRC [10]. In that condition, renal excretion must be able to compensate the high quantity calcium intake.
Plasma phosphorus mean was within the reference interval $(4.5-8.1 \mathrm{mg} / \mathrm{dL})$ reported by Kaneko et al. [8]. Variation was higher than calcemia (Figure 3 ), as a consequence of a less rigorous control of phosphatemia. This mineral showed great oscillations (Figure 4), having higher excretion in the first months of age. Kaneko et al. [8] mentioned a value for urine phosphorus for adult cats $(108 \mathrm{mg} / \mathrm{kg} /$ day $)$, quite similar to that found in the present work $(98.4 \mathrm{mg} / \mathrm{kg} / \mathrm{day})$.

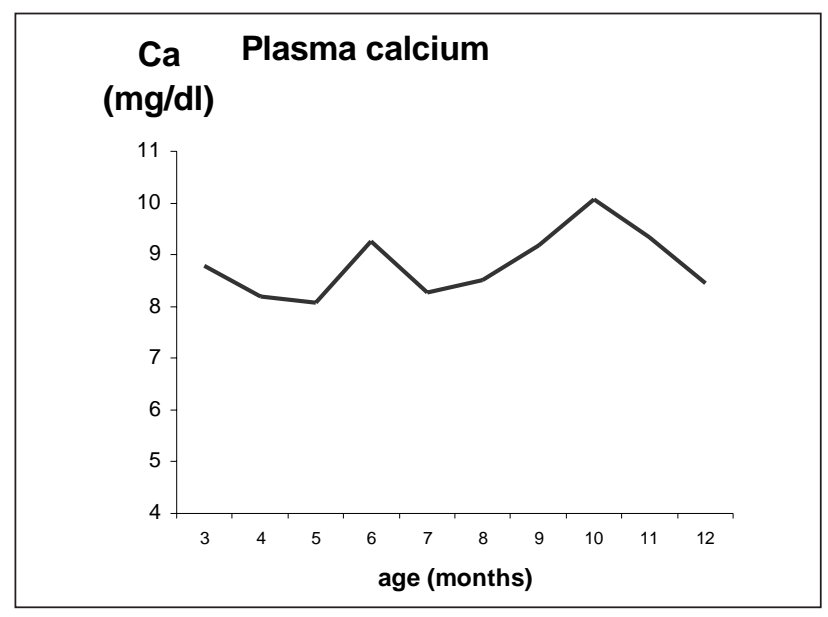

Figure 1. Variation of plasma calcium in growing cats.

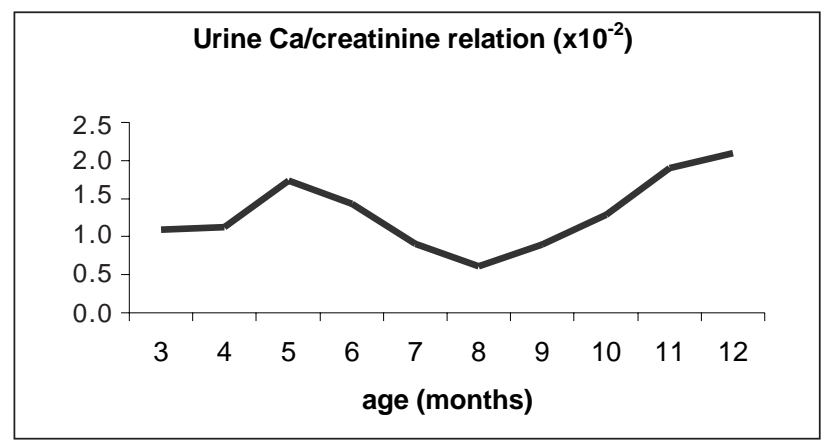

Figure 2. Variation of urinary excretion of calcium in growing cats.

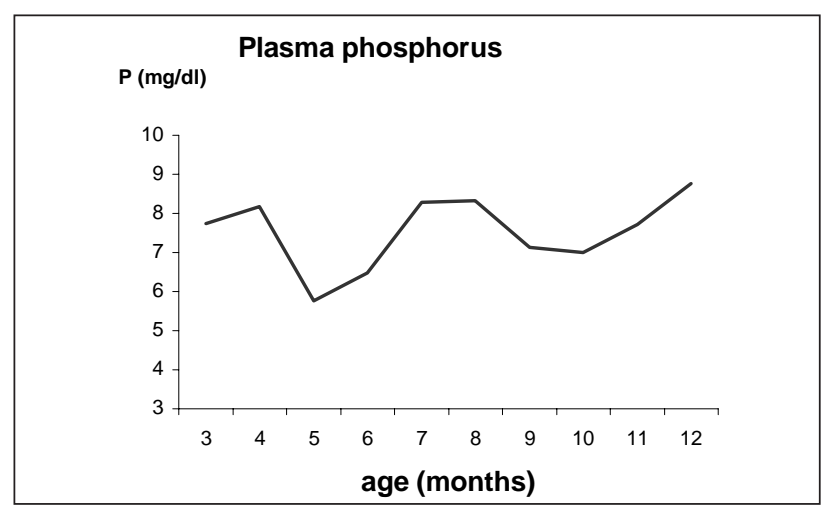

Figure 3. Variation of plasma phosphorus in growing cats. 


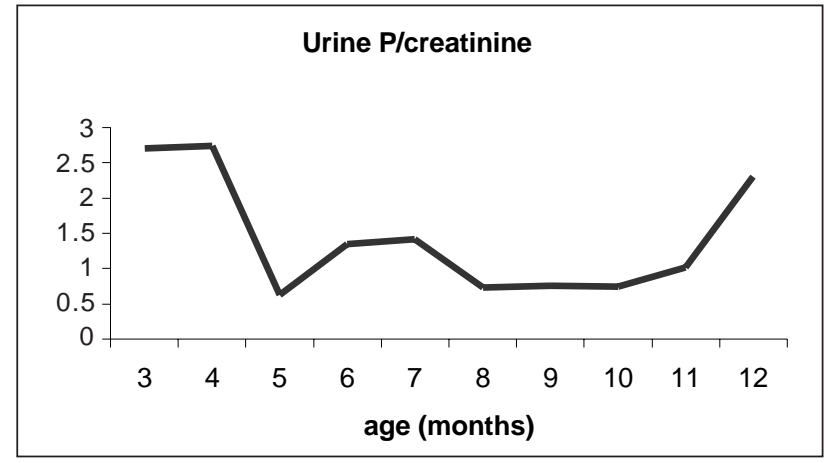

Figure 4. Variation of urinary excretion of phosphorus in growing cats.

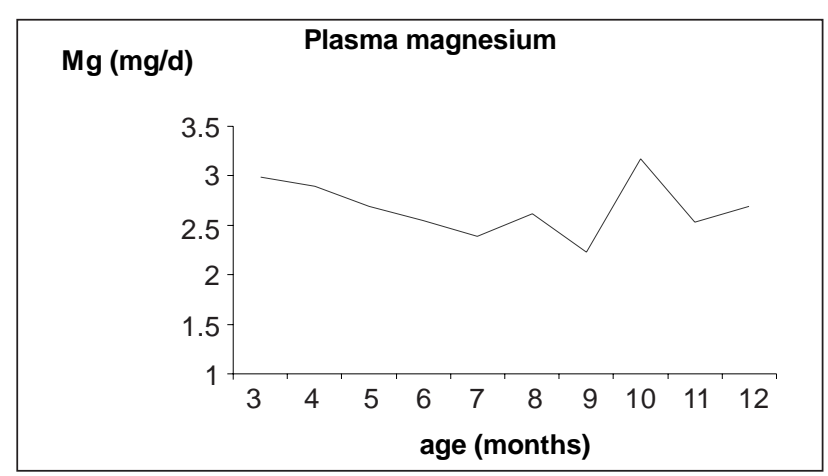

Figure 5. Variation of plasma magnesium in growing cats.

Mean phosphorus in the ration was $0.9 \pm$ $0.29 \%$, which is in adequacy to the guarantee analysis (Table 1). However, the $\mathrm{Ca} / \mathrm{P}$ ratio was $2.87 \pm 1.2$, considered as high, according to the values recommended by Wills and Earle [17] of 0.5 to 2.0, and by NRC [10] of 0.8 to 1.2 . The higher $\mathrm{Ca} / \mathrm{P}$ relation in the diet could be responsible by a higher excretion of $\mathrm{Ca}$ and lower excretion of $\mathrm{P}$. A low urinary excretion of phosphorus has been evoked as a preventive mechanism to avoid struvite calculi formation, because high concentrations of phosphorus in urine, especially in the anion form $\left(\mathrm{PO}_{4}{ }^{3-}\right)$, favored precipitation of those types of crystals. High levels of $\mathrm{P}$ in the diet, besides predispose struvite crystal formation in urine, also could diminish intestinal absorption of $\mathrm{Ca}$ and $\mathrm{Mg}$, by formation of phosphate-Ca-Mg complexes [17].

Overall mean value of plasma magnesium was higher than value cited by Kaneko et al. [8] of $2.2 \mathrm{mg} / \mathrm{dl}$. Urine magnesium had a mean within the reference interval (3-12 mg/kg/day) reported by Kaneko et al. [8].

Albeit the ration manufacturer did not mention the maximum level of magnesium, there was obtain a mean of $0.11 \pm 0.01 \%$, higher than requirement recommended by the NRC [10] of $0.04 \%$. This may have contributed to the

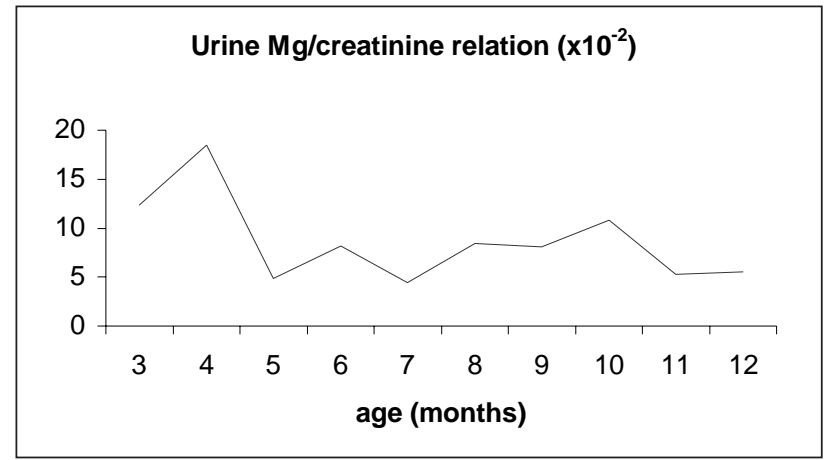

Figure 6. Variation of urinary excretion of magnesium in growing cats.

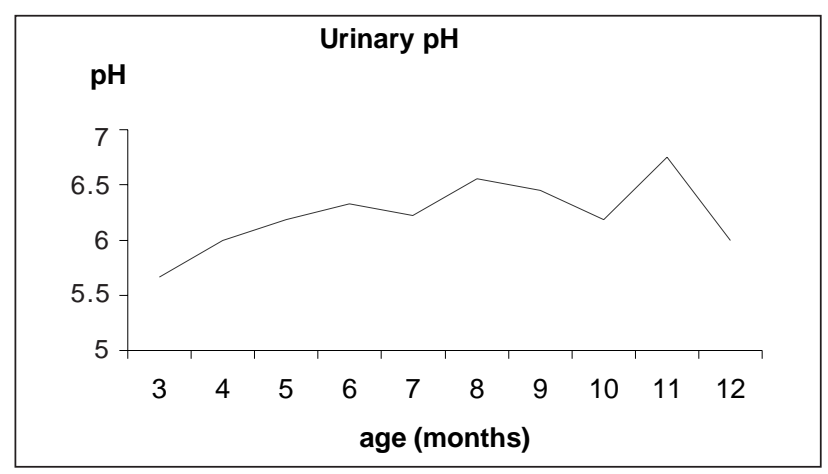

Figure 7. Variation of urinary $\mathrm{pH}$ in growing cats.

higher plasma level found, compared within the reference value. The variation of magnesium urine excretion (Figure 6) showed that, though little variation was found in the ration content, there are other factors affecting magnesium renal excretion, such as level and interaction with other minerals. A very low magnesium excretion is not recommended because this mineral could prevent formation of calcium oxalate calculi, by its competition with calcium to form a more soluble oxalate salt [7].

Overall urinary $\mathrm{pH}$ was lightly acid, with a mean interval considered as physiological. Feline urine $\mathrm{pH}$ may range between 5.5 and 8.5 [1]. To prevent formation of struvite crystals, urinary $\mathrm{pH}$ may vary from 6.2 to 6.4 and to prevent calcium oxalate crystals from 6.6 to 6.8 [1]. To dissolve struvite calculi urinary $\mathrm{pH}$ must reach 5.9 to 6.1. Variation of urinary $\mathrm{pH}$ observed in the present experiment (Figure 7) was between those intervals considered as preventive to struvite calculi formation but not to prevent calcium oxalate uroliths.

Some factors influence $\mathrm{pH}$ value in urine, mainly protein and mineral levels in the diet. Feline nutrition demands a higher protein contribution, which has the effect of lowering urine $\mathrm{pH}$, due to more acid excreted associated to protein metabolism [8]. More acid urine 
avoids struvite crystal formation, but it causes a higher predisposition to form calcium oxalate calculi.

\section{CONCLUSIONS}

The commercial diet studied in growing cats showed levels of calcium beyond nutritional requirements, which led to high urinary excretion of calcium and a diet $\mathrm{Ca} / \mathrm{P}$ ratio above recommended value. Phosphorus variations in plasma and urine suffered higher variations than the other minerals along the first year of age of cats. Magnesium levels in the ration were higher than recommended and plasma concentration was higher than reference interval although magnesium urinary excretion was within the reference values. The urinary $\mathrm{pH}$ values varied from more acidic values in the first months of age to stabilized values, which were considered adequate to prevent struvite crystal but not to prevent oxalate crystals.

\section{SOURCES AND MANUFACTURERS}

${ }^{1}$ Bioclin, Belo Horizonte (Brazil)
${ }^{2}$ Biobrás, Belo Horizonte (Brazil)
${ }^{3}$ Labtest, Lagoa Santa (Brazil)
${ }^{4}$ Tecnalise, Piracicaba (Brazil)

\section{REFERENCES}

1 Allen T.A. \& Kruger J.M. 2000. Feline lower urinary tract disease. In: Hand M.S., Thatcher C.D., Remillard R.L. \& Rodebush P. (Eds). Small Animal Clinical Nutrition. 4th edn. Missouri: Mark Morris Institute, pp.321-354.

2 Barsanti J.A. 1982. Feline urologic syndrome: further investigation into ethiology. Journal of the American Animal Hospital Association. 391: 345-353.

3 Buffington C.A. 1985. Feline struvite urolithiasis: magnesium effect depends on urinary pH. Feline Practice. 15: 29-38.

4 Buffington C.A. 1994. Lower urinary tract disease in cats - new problems, new paradigms. Journal of Nutrition. 124: 2643-2651.

5 Buffington C.A., Chew D.J. \& Dibartola S.P. 1996. Interstitial cystitis in cats. Veterinary Clinics of North America: Small Animal Practice. 26: 317-326.

6 Ettinger S.J. \& Feldman E.C. 1997. Tratado de Medicina Interna Veterinária.4. ed. São Paulo: Editora Manole, 987p.

7 Feldman B.M., Kennedy B.M. \& Schlstraeta M. 1977. Dietary minerals and feline urologic syndrome. Feline Practice $7: 39$.

8 Kaneko J.J., Harvey J.W. \& Bruss M.L. 1997. Clinical Biochemistry of Domestic Animals. 5th edn. San Diego: Academic Press, 932p.

9 Lawler D.F., Sjolin D.W. \& Collins J.E. 1985. Incidence rates of feline lower urinary tract diseases in the United States. Feline Practice 15: 16.

10 Nutrient Requirements of Cats. 1986. Committee on Animal Nutrition. Washington: National Research Council. 88 p.

11 Osborne C.A., Polzin D.J. \& Kruger J.M. 1989. Relationship of nutritional factors to the cause, dissolution, and prevention of feline uroliths and urethral plugs. Veterinary Clinics of North America: Small Animal Practice. 19: 561-581.

12 Osborne C.A., Lulich J.P. \& Kruger, J.M. 1990. Medical dissolution of feline struvite urocystoliths. Journal of the American Veterinary Medical Association. 196: 1053-1063.

13 Pastoor F.J.H., Van Klooster A.T., Mathot J.N. \& Beynen A.C. 1994. Increasing calcium intakes lower urinary concentrations of phosphorus and magnesium in adult ovariectomized cats. Journal of Nutrition. 124: 299-304.

14 Pastoor F.J.H., Van Klooster A.T., Opitz R., Beynen A.C. 1995. Effect of dietary magnesium level on urinary and faecal excretion of calcium, magnesium and phosphorus in adult, ovariectomized cats. Bristish Journal of Nutrition. 74: 77-84.

15 Tumchai R., Lulich J. \& Osborne C.A. 1996. Epizootiologic evaluation of urolithiasis in cats: 3498 cases (1982-1992). Journal of the American Veterinary Medical Association. 208: 547-551.

16 Weaver C.M. 1990. Assessing calcium status and metabolism. Journal of Nutrition. 120: 1470-1473.

17 Wills J. \& Earle K.E. 1995. Nutrición y transtornos nutricionales. In: Wills J. \& Wolf A. (Eds). Manual de Medicina Felina. Zaragoza: Editorial Acribia, pp. 63-85. 